\title{
Kinetic, Equilibrium and Thermodynamic Studies of the Biosorption of Heay Metals by Ceratonia Siliqua Bark
}

\author{
Ahlam M. Farhan', Nidá M. Salem², Ahmad L. Ahmad², Akl M. Awwad ${ }^{3, *}$ \\ ${ }^{1}$ Department of Chemistry, Faculty of Science for Women, Baghdad University, Baghdad, Iraq \\ ${ }^{2}$ Department of Plant Protection, Faculty of Agriculture, Jordan University, Amman, Jordan \\ ${ }^{3}$ Department of Knowledge, Royal Scientific Society, El Hassan Science City, Amman, Jordan
}

\begin{abstract}
Biosorption of $\mathrm{Zn}(\mathrm{II}), \mathrm{Ni}(\mathrm{II}), \mathrm{Cu}(\mathrm{II})$ and $\mathrm{Cd}(\mathrm{II})$ ions from aqueous solutions onto Ceratonia siliqua (Carob tree) bark has been investigated in a batch biosorption process. The biosorption process was found to be dependent on $\mathrm{pH}$ of solution, initial metal ion concentration, biosorbent dose, contact time and temperature. The experimental equilibrium biosorption data were analyzed by Langmuir, Freundlich, Temkin and Dubinin-Radushkevic isotherm models. The Langmuir model gave a better fit than the other three models by higher correlation coefficient, $R^{2}$. The maximum biosorption capacity calculated from the Langmuir isotherm was $42.19 \mathrm{mg} / \mathrm{g}, 31.35 \mathrm{mg} / \mathrm{g}, 21.65 \mathrm{mg} / \mathrm{g}$ and $14.27 \mathrm{mg} / \mathrm{g}$ for $\mathrm{Ni}(\mathrm{II}), \mathrm{Zn}(\mathrm{II}), \mathrm{Cu}(\mathrm{II})$ and $\mathrm{Cd}(\mathrm{II})$, respectively at optimum conditions. The kinetic studies indicated that the biosorption process of the metal ions followed well pseudo-second-order model. The negative values of $\Delta \mathrm{G}^{\circ}$ and the positive $\Delta \mathrm{H}^{\circ}$ revealed that the biosorption process was spontaneous and endothermic. According to the biosorption capacity, Ceratonia siliqua bark considered as an effective, low cost, and environmentally friendly biosorbent for the removal of metal ions ions from aqueous solutions.
\end{abstract}

Keywords Biosorption, Ceratonia siliqua bark, Ni(II), Zn(II), Cd(II), Cu(II), Kinetic, Thermodynamic

\section{Introduction}

The major sources of $\mathrm{Ni}(\mathrm{II}), \mathrm{Zn}(\mathrm{II}), \mathrm{Cu}(\mathrm{II})$ and $\mathrm{Cd}(\mathrm{II})$ ions release into the environment by waste streams are electroplating, leather tanning, paint dyes and textiles industries. Different methods of treating effluents containing metals have been developed over years which include chemical precipitation, chemical oxidation or reduction, electrochemical treatment, ion exchange, reverse osmosis, filtration, evaporation recovery, adsorption, and electrocoagulation[1-8]. These methods have significant disadvantages, including high energy requirements, incomplete metal removal, generation toxic sludge needs treatment and expensive equipments. The search for novel technologies has recently been directed to the application of biosorption, which constitutes an attractive to common applied physical-chemical methods. The advantages of biosorption lie in the good performance in metal removal, cost-effectiveness and eco-friendly to environment. Many biomaterials have been investigated as biosorbents for removal of heavy metals such as leaf, stem and root phytomass of Quercus ilex[9], pomegranate peel[10], banana (Musa paradisiaca), lemon (Citrus limonum) and orange (Citrus sinensis) peel[11], rice husk[12], peanut

* Corresponding author:

Amawwad2000@yahoo.com (A. M. Awwad)

Published online at http://journal.sapub.org/chemistry

Copyright (C) 2012 Scientific \& Academic Publishing. All Rights Reserved husk[13], neem leaf[14], hazelnut, walnut and almond shell [15], Ulmus carinifolia and Fraxinus excelsior leaves[16], processed walnut shell[17], sugar cane bagasse[18], walnut, hazelnut, almond, pistachio and apricot stone[19], Lagenaria vulgaris shell[20], olive leaves[21], Eriobotrya japonica[22], grape stalk waste[23], Pinus sylvestriis[24], Eucalyptus bark saw dust, mango bark saw dust, and pineapple fruit peel[25]. ceratonia siliqua tree is native to the Mediterranean region and grows up to 10 meters tall. Its crown is broad and semi-spherical, supported by a thick trunk with brown rough bark.

The present study describes a new biosorbent Ceratonia siliqua bark (carob bark) for the biosorption of Ni(II), $\mathrm{Zn}$ (II), $\mathrm{Cu}$ (II) and $\mathrm{Cd}$ (II) ions from aqueous solutions. The effects of different parameters such as the $\mathrm{pH}$ of the solution, the initial metal concentration, the dose of the absorbent, the contact time and temperature were investigated.

\section{Materials and Methods}

\subsection{Adsorbent}

Ceratonia siliqua bark was collected from a local carob trees at Royal Scientific Society Campus, Amman, Jordan. C. siliqua bark was thoroughly rinsed with distilled water to remove dust and soluble materials and then it was allowed to dry at room temperature. The dried C. siliqua was crushed 
and grounded to a fine powder in a grinding mill (Retsch RM 100 ) and sieved to get size fraction $<44 \mu \mathrm{m}$. The $C$. siliqua bark powder was dried in an oven at $60^{\circ} \mathrm{C}$ for $6 \mathrm{~h}$ and then stored in a desiccator to be used for the batch experiments.

\subsection{Materials}

All chemicals used were analytical grade purchased from Fluka AG. Stock solutions of $1000 \mathrm{mg} / \mathrm{L}$ were prepared by dissolving $\mathrm{NiSO}_{4} \cdot 6 \mathrm{H}_{2} \mathrm{O}, \mathrm{ZnSO}_{4} .7 \mathrm{H}_{2} \mathrm{O}, \mathrm{Cu}\left(\mathrm{NO}_{3}\right)_{2} .5 \mathrm{H}_{2} \mathrm{O}$ and $\mathrm{Cd}\left(\mathrm{NO}_{3}\right)_{2}$ in distilled deionized water. Desired test solutions of metal ions were prepared using appropriate subsequent dilutions of the stock solutions. The range of concentrations of metal ions prepared from standard solution varies between 5 and $100 \mathrm{mg} / \mathrm{L}$. Before mixing the adsorbent, the $\mathrm{pH}$ of each test solution was adjusted to the required value with $0.1 \mathrm{M}$ $\mathrm{NaOH}$ or $0.1 \mathrm{M} \mathrm{HCl}$.

\subsection{Analysis}

The concentrations of metal ions in the solutions before and after equilibrium were determined by atomic absorption spectrometer (AAS-6300, Shimadzu, Japan). The pH of the solution was measured with a WTW $\mathrm{pH}$ meter using a combined glass electrode. Fourier transform infrared spectroscopy, FT-IR (IR Prestige-21, Shimadzu, Japan) was used to identify the different chemical functional groups present in $C$. siliqua bark. FT-IR analysis also used to determine the functional groups which are responsible for the metal binding with $C$. siliqua bark. The analysis was carried out using $\mathrm{KBr}$ and the spectral range varying from 4000 to $400 \mathrm{~cm}^{-1}$.

\subsection{Batch Biosorption Experiments}

Batch biosorption experiments were conducted by mixing biosorbent with metal ion solution with desired concentration in $250 \mathrm{~mL}$ glass flask. The glass flasks were stoppered during the equilibration period and placed on a temperature controlled shaker at a speed $120 \mathrm{r} / \mathrm{min}$. The effect of $\mathrm{pH}$ on the equilibrium biosorption of $\mathrm{Ni}(\mathrm{II}), \mathrm{Zn}(\mathrm{II})$, $\mathrm{Cu}(\mathrm{II})$ and $\mathrm{Cd}(\mathrm{II})$ was investigated by mixing, The amount of biosorption was calculated based on the difference between the initial $\left(C_{\mathrm{o}}, \mathrm{mg} / \mathrm{L}\right)$ and final concentration $\left(C_{\mathrm{e}}, \mathrm{mg} / \mathrm{L}\right)$ in every flask, as follows:

$$
q_{e}=\frac{C_{o}-C_{e}}{M} x V
$$

where $q_{\mathrm{e}}$ is the metal uptake capacity $(\mathrm{mg} / \mathrm{g}), V$ the volume of the metal solution in the flask (L) and $M$ is the dry mass of biosorbent $(\mathrm{g})$. Percent removal $(\% \mathrm{R})$ of metal ions was calculated from the following equation:

$$
\% R=\frac{C_{o}-C_{e}}{C_{o}} \times 100
$$

\section{Results and Discussion}

\subsection{Effect of $\mathbf{p H}$}

The effect of $\mathrm{pH}$ on the biosorption of metal ions onto $\mathrm{C}$. siliqua bark was studied at $\mathrm{pH}$ 1.0-8.0. The maximum biosorption was observed at $\mathrm{pH}$ 5.0-6.0 for metal ions. Therefore, the remaining all biosorption experiments were carried out at this $\mathrm{pH}$ values.

\subsection{Effect of Initial Metal Concentration}

$\mathrm{Ni}(\mathrm{II}), \mathrm{Zn}(\mathrm{II}), \mathrm{Cu}(\mathrm{II})$ and $\mathrm{Cd}(\mathrm{II})$ ions biosorption by $\mathrm{C}$. siliqua bark was studied in batch experiments (pH 5.0-6.0) using different initial metal concentrations of 5, 20, 40, 60, 80 and $100 \mathrm{mg} / \mathrm{L}$. The equilibrium uptake of the biosorbent was observed increasing gradually with an increasing the initial concentration of metal ions. The increase of biosorption yield with the increase in metal ions concentration is probably due to higher interaction between the metal ions and sequestering sites of biosorbent

\subsection{Effect of contact time}

The rate of biosorption is important for designing batch biosorption experiments. Therefore, the effect of contact time on the biosorption of metal was investigated. The biosorption of $\mathrm{Ni}(\mathrm{II}), \mathrm{Zn}(\mathrm{II}), \mathrm{Cu}(\mathrm{II})$ and $\mathrm{Cd}(\mathrm{II})$ ions increased considerably until the contact time reached 80 min at $30^{\circ} \mathrm{C}$. Further increase in contact time did not enhance the biosorption, so, the optimum contact time was selected as $80 \mathrm{~min}$ for further experiments.

\subsection{Effect of adsorbent dose on biosorption}

The biosorbent dosage is an important parameter because this determines the capacity of a biosorbent for a given initial metal concentration. The biosorption efficiency for $\mathrm{Ni}(\mathrm{II}), \mathrm{Zn}(\mathrm{II}), \mathrm{Cu}(\mathrm{II})$ and $\mathrm{Cd}(\mathrm{II})$ ions as a function of biosorbent dosage was investigated. The percentage of the metal biosorption steeply increases with the biosorbent loading up to $5 \mathrm{~g} / \mathrm{L}$. This result can be explained by the fact that the biosorption sites remain unsaturated during the biosorption reaction whereas the number of sites available for biosorption site increases by increasing the biosorbent dose. The maximum biosorption for $\mathrm{Ni}(\mathrm{II}), \mathrm{ZN}(\mathrm{II}), \mathrm{Cu}(\mathrm{II})$ and $\mathrm{Cd}(\mathrm{II})$ was attained at biosorbent dosage, $5 \mathrm{~g} / \mathrm{L}$. Therefore, the optimum biosorbent dosage was taken as 5 $\mathrm{g} / \mathrm{L}$ for further experiments.

\subsection{Biosorption Isotherms}

An adsorption isotherm describes the fraction of sorbate molecules that are partitioned between liquid and solid phases at equilibrium. Biosorption of $\mathrm{Ni}(\mathrm{II}), \mathrm{Zn}$ (II), $\mathrm{Cu}(\mathrm{II})$ and $\mathrm{Cd}(\mathrm{II})$ ions onto $C$. siliqua bark powder was modeled using four adsorption isotherms.

The Langmuir isotherm assumes monolayer adsorption on a uniform surface with a finite number of adsorption sites. Once a site is filled, no further sorption can take place at that site. As such the surface will eventually reach a saturation point where the maximum adsorption of the surface will be achieved. The linear form of the Langmuir isotherm model is described as[26]: 


$$
\frac{C_{e}}{q_{e}}=\frac{1}{K_{L} q_{\max }}+\frac{1}{q_{\max }} C e
$$

where $K_{L}$ is the Langmuir constant related to the energy of adsorption and $q_{\max }$ is the maximum biosorption capacity $(\mathrm{mg} / \mathrm{g})$. Values of Langmuir parameters $q_{\max }$ and $K_{L}$ were calculated from the slope and intercept of the linear plot of $C_{e} / q_{e}$ versus $C_{e}$ as shown in Figure 1. Values of $q_{\max }, K_{L}$ and regression coefficient $R^{2}$ are listed in Table 1 . These values for $C$. siliqua powder biosorbent indicated that Langmuir model describes the biosorption phenomena favorable. The essential characteristics of the Langmuir isotherm parameters can be used to predict the affinity between the sorbate and sorbent using separation factor or dimensionless equilibrium parameter, $R_{\mathrm{L}}$ expressed as in the following equation:

$$
R_{L}=\frac{1}{\left(1+K_{L} C_{o}\right)}
$$

The value of $R_{\mathrm{L}}$ indicated the type of Langmuir isotherm to be irreversible $\left(R_{\mathrm{L}}=0\right)$, favorable $\left(0<R_{\mathrm{L}}<1\right)$, linear $\left(R_{\mathrm{L}}=1\right)$ or unfavorable $\left(R_{\mathrm{L}}>1\right)$. The $R_{\mathrm{L}}$ was found to be $0.25-0.86$ for concentration of $5-100 \mathrm{mg} / \mathrm{L}$ of metal ions. They are in the range of $0-1$ which indicates the favorable biosorption.

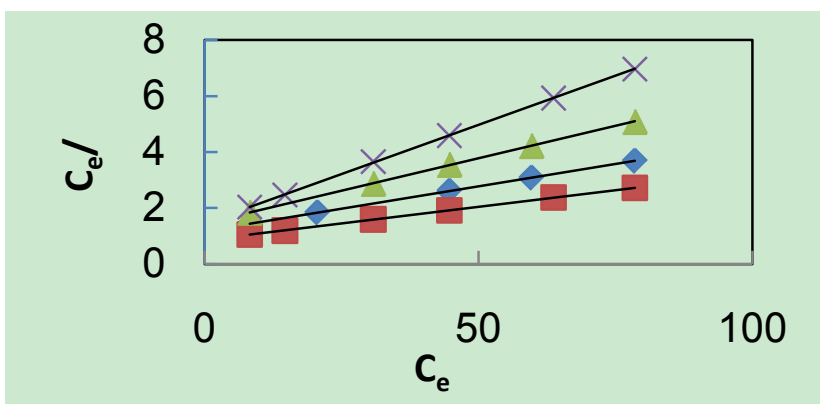

Figure 1. Langmuir isotherm for $\mathbf{n}, \mathrm{Ni}(\mathrm{II}) ; \bullet, \mathrm{Zn}(\mathrm{II}) ; \boldsymbol{\Delta}, \mathrm{Cu}(\mathrm{II}) ; \mathrm{X}, \mathrm{Cd}(\mathrm{II})$ ions biosorption onto C. siliqua bark

The Freundlich isotherm model is the well known earliest relationship describing the adsorption process. This model applies to adsorption on heterogeneous surfaces with the interaction between adsorbed molecules and the application of Freundlich equation also suggests that sorption energy exponentially decreases on completion of the sorption centers of an adsorbent. This isotherm is an empirical equation and can be employed to describe heterogeneous systems and is expressed as follows in linear form[27]:

$$
\ln q_{e}=\ln K_{F}+\frac{1}{n} \ln C_{e}
$$

where $K_{F}$ is the Freundlich constant related to the bonding energy. $1 / n$ is the heterogeneity factor and $n(\mathrm{~g} / \mathrm{L})$ is a measure of the deviation from linearity of adsorption. Freundlich equilibrium constants were determined from the plot of $\ln q_{e}$ versus $\ln C_{e}$, Figure 2 on the basis of the linear of Freundlich equation. The $n$ value indicates the degree of non-linearity between solution concentration and adsorption as follows: if $n=1$, then adsorption is linear; if $n<1$, then adsorption is a chemical process; if $n>1$, then adsorption is a physical process. The $n$ value in Freundlich equation was found to be $1.73-2.21$ for $C$. Siliqua bark powder, Table 1 . Since $n$ lie between 1 and 10 , this indicate the physical biosorption of metal ions onto C. siliqua bark .

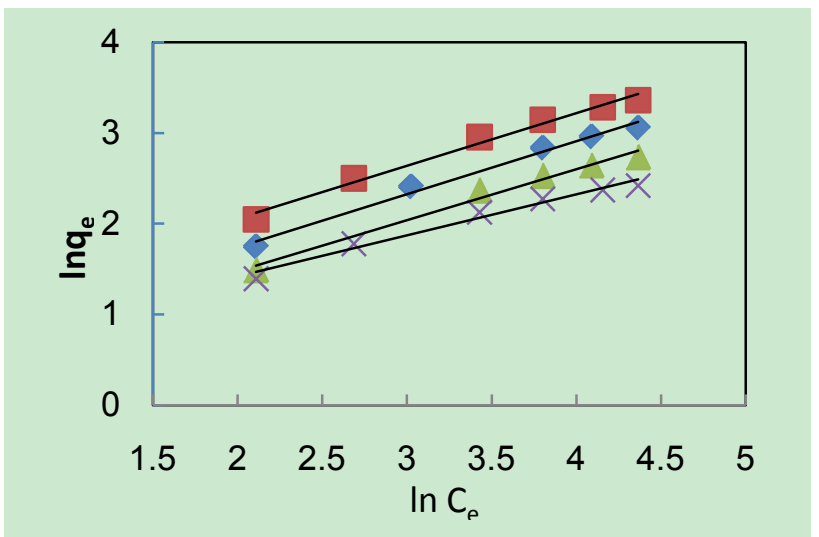

Figure 2. Freundlich isotherm for $\boldsymbol{\bullet}, \mathrm{Ni}(\mathrm{II})$;, $\mathrm{Zn}(\mathrm{II})$; $\boldsymbol{\Delta}, \mathrm{Cu}(\mathrm{II})$; X, Cd(II) ions biosorption onto $C$. siliqua bark

Temkin isotherm equation[28] assumes that the heat of biosorption of all the molecules in the layer decreases linearly with coverage due to adsorbent-adsorbate interactions and that the adsorption is characterized by a uniform distribution of the binding energies up to some maximum binding energy. The Temkin isotherm has been used in the linear form as follows:

$$
q_{e}=\frac{R T}{b_{T}} \ln A_{T}+\frac{R T}{b_{T}} \ln C_{e}
$$

A plot of $\mathrm{q}_{\mathrm{e}}$ versus $\ln \mathrm{C}_{\mathrm{e}}$ enables the determination of the isotherm constants $b_{T}$ and $A_{T}$ obtained from the slope and the intercept, Figure 3. Where $A_{T}(\mathrm{~L} / \mathrm{mg})$ is the equilibrium binding constant corresponding to the maxmium binding energy and constant $b_{\mathrm{T}}$ is related to the heat of biosorption, Table 1.

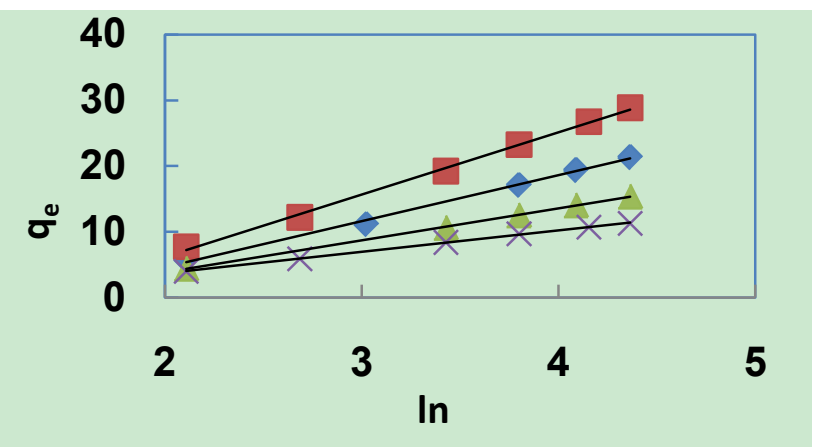

Figure 3. Temkin isotherm for $\mathbf{m}, \mathrm{Ni}(\mathrm{II}) ; \bullet, \mathrm{Zn}(\mathrm{II}) ; \boldsymbol{\Lambda}, \mathrm{Cu}(\mathrm{II})$; $\mathrm{X}, \mathrm{Cd}(\mathrm{II})$ ions biosorption onto $C$. siliqua bark

Dubinin-Radushkevich (D-R) model, which does not assume a homogenous surface or a constant biosorption potential as the Langmuir model, was also used to test the experimental data[29].

$$
\ln q_{e}=\ln q_{d}-\beta \varepsilon^{2}
$$

Where $\varepsilon$ can be correlated to $\mathrm{C}_{\mathrm{e}}(\mathrm{mg} / \mathrm{L})$ by the following equation: 


$$
\varepsilon=R T \ln \left(1+1 / C_{e}\right)
$$

Where $\mathrm{R}$ is the gas universal $(8.314 \mathrm{~J} / \mathrm{mol} \mathrm{K})$ and $\mathrm{T}$ is the absolute temperature $(\mathrm{K})$. The $\mathrm{D}-\mathrm{R}$ isotherm parameters $\beta$ and $\mathrm{q}_{\mathrm{d}}$ were obtained from the slope and intercept of the plot of $\ln \mathrm{q}_{\mathrm{e}}$ versus $\varepsilon^{2}$, Figure 4 . The calculated vales are listed in Table 1. The values of correlation coefficient were lower than that of other three isotherm values. In all cases, the D-R model represents the least fit to experimental data than the other isotherms models.

Table 1. Langmuir, Freundlich, D-R and Temkin isotherm constants for biosorption of metal ions onto Ceratonia siliqua bark

\begin{tabular}{|cccc|}
\hline Langmuir & $\mathrm{q}_{\max }(\mathrm{mg} / \mathrm{g})$ & $\mathrm{K}_{\mathrm{L}}(\mathrm{L} / \mathrm{mg})$ & $\mathrm{R}^{2}$ \\
\hline $\mathrm{Ni}(\mathrm{II})$ & 42.19 & 0.03 & 0.9999 \\
$\mathrm{Zn}(\mathrm{II})$ & 31.35 & 0.03 & 0.9999 \\
$\mathrm{Cd}(\mathrm{II})$ & 21.65 & 0.031 & 0.9999 \\
$\mathrm{Cu}(\mathrm{II})$ & 14.27 & 0.048 & 0.9999 \\
\hline $\mathrm{Temkin}$ & $\mathrm{b}_{\mathrm{T}}(\mathrm{J} / \mathrm{mol})$ & $\mathrm{K}_{\mathrm{T}}(\mathrm{L} / \mathrm{g})$ & $\mathrm{R}^{2}$ \\
\hline $\mathrm{Ni}(\mathrm{II})$ & 265.82 & 0.995 & 0.9975 \\
$\mathrm{Zn}(\mathrm{II})$ & 298.55 & 0.995 & 0.9924 \\
$\mathrm{Cd}(\mathrm{II})$ & 586.69 & 0.998 & 0.9993 \\
$\mathrm{Cu}(\mathrm{II})$ & 775.84 & 0.999 & 0.9983 \\
\hline $\mathrm{Freundlich}$ & $\mathrm{n}$ & $\mathrm{K}_{\mathrm{F}}$ & $\mathrm{R}^{2}$ \\
\hline $\mathrm{Ni}(\mathrm{II})$ & 1.73 & 2.46 & 0.9853 \\
$\mathrm{Zn}(\mathrm{II})$ & 1.71 & 1.77 & 0.9875 \\
$\mathrm{Cd}(\mathrm{II})$ & 1.77 & 1.76 & 0.9835 \\
$\mathrm{Cu}(\mathrm{II})$ & 2.21 & 1.68 & 0.9768 \\
\hline $\mathrm{D}-\mathrm{R}$ & $\beta$ & 2.945 & 0.8702 \\
\hline $\mathrm{Ni}(\mathrm{II})$ & $3.00 \mathrm{E}-05$ & 5.49 & 0.9088 \\
$\mathrm{Zn}(\mathrm{II})$ & $4.00 \mathrm{E}-05$ & 5.74 & 0.8031 \\
$\mathrm{Cd}(\mathrm{II})$ & $1.00 \mathrm{E}-04$ & & $\mathrm{R}^{2}$ \\
$\mathrm{Cu}(\mathrm{II})$ & $3.00 \mathrm{E}-05$ & $\mathrm{~g})$ & 0.7739 \\
\hline & & 2.309 & 2.95 \\
\hline
\end{tabular}

The mean free energy of biosorption, E defined as the free energy change when 1 mole of ion is transferred to the surface of the solid from infinity in solution and calculated from the $\beta$ value using the following equation:

$$
\beta=\frac{1}{\sqrt{2 \beta}}
$$

If the magnitude of $\mathrm{E}$ is between 8 to $16 \mathrm{KJ} / \mathrm{mol}$, then the sorption process is supposed to proceed via chemisorption reaction, while for values of $\mathrm{E}$ is less than $8 \mathrm{~kJ} / \mathrm{mol}$, the sorption process is of physical nature. The vale of $\mathrm{E}$ calculated from equation (9) for the biosorption of metal ions by $C$. siliqua bark is $0.13 \mathrm{~kJ} / \mathrm{mol}$. This indicates that the biosorption process is of physical nature.

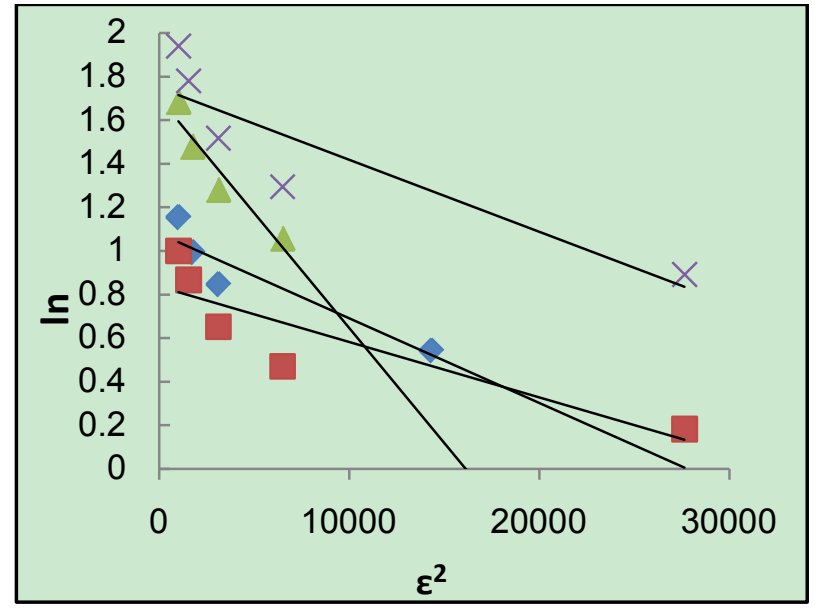

Figure 4. D-R isotherm for $\mathbf{m}, \mathrm{Ni}(\mathrm{II})$;, $\mathrm{Zn}(\mathrm{II}) ; \boldsymbol{\Delta}, \mathrm{Cu}(\mathrm{II})$; $\mathrm{X}, \mathrm{Cd}(\mathrm{II})$ ions biosorption onto C. siliqua bark

\subsection{Biosorption Kinetics}

Parameters from two kinetic models, pseudo first-order and pseudo second-order were fit to experimental data to examine the biosorption kinetics of metal uptake onto $C$. siliqua bark. The pseudo-first order equation of Lagergren [30] is generally expressed as follows:

$$
\frac{d q_{t}}{d t}=k_{1}\left(q_{e}-q_{t}\right)
$$

Where $q_{e}$ and $q_{t}$ are the sorption capacities at equilibrium and at time $t$, respectively $(\mathrm{mg} / \mathrm{g})$ and $k_{1}$ is the rate constant of pseudo-first order sorption, ( $1 / \mathrm{min})$. After integration and applying boundary conditions, $q_{t}=0$ to $q_{\mathrm{t}}=q_{\mathrm{t}}$ at $t=0$ to $t=t$; the integrated form of equation becomes:

$$
\log \left(q_{e}-q_{t}\right)=\log q_{e}-\frac{k_{1}}{2.303} t
$$

The equation applicable to experimental results generally differs from a true first order equation in two ways: the parameter $k_{l}\left(q_{e}-q_{t}\right)$ does not represent the number of available sites; and the parameter $\log q_{e}$ is an adjustable parameter which is often not found equal to the intercept of a plot of $\log \left(\mathrm{q}_{\mathrm{e}}-\mathrm{q}_{\mathrm{t}}\right)$ against $t$, whereas in a true first order sorption reaction $\log q_{e}$ should be equal to the intercept of $\log \left(q_{e}-q_{t}\right)$ against $t$. In order to fit equation 11 to experimental data, the equilibrium sorption capacity, $q_{e}$ must be known. In many cases is unknown and as chemisorption tends to become un measurably slow, the amount sorbed is still significantly smaller than the equilibrium amount. In most cases in the literature, the pseudo-first order equation of Lagergren does not fit well for the whole range of contact time and is generally applicable over the initial 20 to 80 minutes of the sorption process. Furthermore, one has to find some means of extrapolating the experimental data to $t=\infty$, on treating $q_{e}$ as an adjustable parameter to be determined by trial and error. For this reason, it is therefore necessary to use trial and error to obtain the equilibrium sorption capacity, in order to analyze the pseudo-first order model kinetics. The pseudo first order rate constant can be obtained from the slope of plot between $\log \left(q_{e}-q_{t}\right)$ against time $(t)$, Figure 5 . 
The calculated values and their corresponding linear regression correlation coefficient values are listed in Table 2. $R^{2}$ was found to be $0.8718-0.9391$, which shows that this model cannot be applied to predict the adsorption kinetic model.

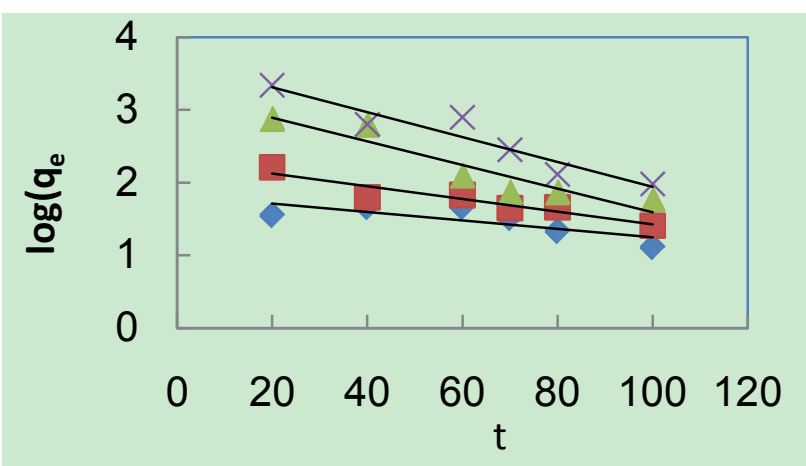

Figure 5. Pseudo-first order kinetics for $\bullet, \mathrm{Ni}(\mathrm{II})$; $\mathbf{}, \mathrm{Zn}(\mathrm{II})$; $\boldsymbol{\Delta}, \mathrm{Cu}(\mathrm{II}$; $\mathrm{x}$, $\mathrm{Cd}$ (II) biosorption onto C. siliqua bark

The pseudo second-order rate expression, which has been applied for analyzing chemisorption kinetics rate, is expressed as:

$$
\frac{d q_{t}}{d t}=k\left(q_{e}-q_{t}\right)^{2}
$$

Where $q_{e}$ and $q_{t}$ are the sorption capacity at equilibrium and at time $t$, respectively $(\mathrm{mg} / \mathrm{g})$ and $k$ is the rate constant of pseudo-second order sorption, (g/mg $\mathrm{min})$. For the boundary conditions to $q_{t}=0$ to $q_{t}=q_{t}$ at $t=0$ to $t=t$; ; the integrated form of equation becomes:

$$
\frac{t}{q_{e}}=\frac{1}{K_{2} q_{e}{ }^{2}}+\frac{1}{q_{e}} t
$$

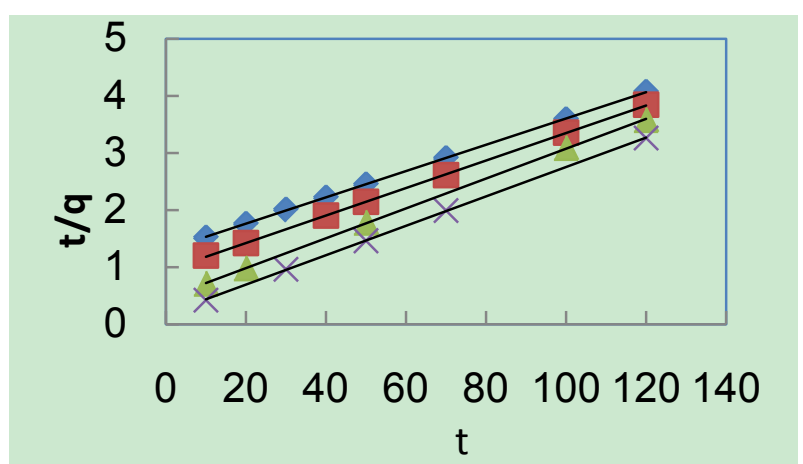

Figure 6. Pseudo-second order kinetics for $\downarrow, \mathrm{Ni}(\mathrm{II}), \mathbf{m}, \mathrm{Zn}(\mathrm{II}), \boldsymbol{\Lambda}, \mathrm{Cu}(\mathrm{II})$, $\mathrm{X}, \mathrm{Cd}(\mathrm{II})$ ions biosorption onto C. siliqua bark

Where $t$ is the contact time ( $\mathrm{min}), q_{e}(\mathrm{mg} / \mathrm{g})$ and $q_{t}(\mathrm{mg} / \mathrm{g})$ are the amount of the solute adsorbed at equilibrium and at any time, $t$. If pseudo-second order kinetics is applicable, the plot of $t / q_{t}$ versus $t$ of the equation should give a linear relationship, from which $q_{e}$ and $k_{2}$ can be determined from the slope and intercept of the plot, Figure 6 . The pseudo-second order rate constant $k_{2}$, the calculated $q_{e}$ value and the corresponding linear regression correlation coefficient value are given in Table 2. At all initial metal concentrations, the linear regression correlation coefficient $R^{2}$ values were higher. The higher values confirm that the adsorption data are well represented by pseudo-second order kinetics

Table 2. Kinetic parameters of metal ions biosorption onto C. siliqua bark

\begin{tabular}{|cccc|}
\hline ist order & $K_{I}$ & $q_{e}(\mathrm{mg} / \mathrm{g})$ & $R^{2}$ \\
\hline $\mathrm{Ni}(\mathrm{II})$ & 0.0067 & 5.76 & 0.9391 \\
$\mathrm{Zn}(\mathrm{II})$ & 0.0064 & 4.53 & 0.8876 \\
$\mathrm{Cu}(\mathrm{II})$ & 0.0067 & 3.39 & 0.8963 \\
$\mathrm{Cd}(\mathrm{II})$ & 0.0111 & 3.95 & 0.8718 \\
\hline $2 \mathrm{nd}$ order & $K_{2}$ & $q_{e}(\mathrm{mg} / \mathrm{g})$ & $R^{2}$ \\
\hline $\mathrm{Ni}(\mathrm{II})$ & 0.0005 & 43.48 & 0.9999 \\
$\mathrm{Zn}(\mathrm{II})$ & 0.0006 & 41.67 & 0.9998 \\
$\mathrm{Cu}(\mathrm{II})$ & 0.0022 & 35.21 & 0.9999 \\
$\mathrm{Cd}(\mathrm{II})$ & 0.0441 & 31.45 & 0.9999 \\
\hline
\end{tabular}

\subsection{Thermodynamic Parameters}

In order to describe thermodynamic behaviour of the biosorption of metal ions onto $C$. siliqua bark, thermodynamic parameters including the change in free energy $\left(\Delta \mathrm{G}^{\circ}\right)$, enthalpy $\left(\Delta \mathrm{H}^{\circ}\right)$ and entropy $(\Delta \mathrm{S} \circ)$ were calculated from following equations[31,32]:

$$
\Delta G^{o}=-R T \ln K_{D}
$$

where $\mathrm{R}$ is the universal gas constant $(8.314 \mathrm{~J} / \mathrm{mol} \mathrm{K}), \mathrm{T}$ $(\mathrm{K})$ is the temperature and $\mathrm{K}_{\mathrm{D}}$ is the distribution coefficient. The thermodynamic equilibrium constant $\left(K_{\mathrm{D}}\right)$ of the adsorption is defined as:

$$
K_{D}=\frac{C_{a}}{C_{e}}
$$

where, $C_{\mathrm{a}}$ is mg of adsorbate adsorbed per liter and $C_{\mathrm{e}}$ is the equilibrium concentration of solution, mg/L. According to thermodynamics, the Gibb's free energy change is also related to the enthalpy change $\left(\Delta H^{\circ}\right)$ and entropy change $\left(\Delta S^{\circ}\right)$ at constant temperature by the Van't Hoff equation:

$$
\Delta G^{o}=\Delta H^{o}-T \Delta S^{o}
$$

Equations (14) and (15) can be written as:

$$
\begin{gathered}
-R T \ln K_{D}=\Delta H^{o}-T \Delta S^{o} \\
\ln K_{D}=-\frac{\Delta H^{o}}{R T}+\frac{\Delta S^{o}}{R}
\end{gathered}
$$

According to the equation 18, the values of enthalpy change $\left(\Delta \mathrm{H}^{\circ}\right)$ and entropy change $\left(\Delta \mathrm{S}^{\circ}\right)$ were calculated from the slope and intercept of the plot of $\ln \mathrm{K}_{\mathrm{D}}$ vs. $1 / \mathrm{T}$. The calculated values of thermodynamic paramours $\Delta \mathrm{G}^{\circ}$, $\Delta \mathrm{H}^{\circ}$, and $\Delta \mathrm{S} \circ$ for the biosorption of metal ions onto $C$. siliqua are reported in Table 3. A negative value of the free energy $\left(\Delta G^{\circ}\right)$ indicated the spontaneous nature of the biosorption process. It was also noted that the change in free energy, increases with increase in which exhibits an increase in adsorption with rise in temperature. This could be possibly because of activation of more sites on the surface of $C$. siliqua bark with increase in temperature or 
that the energy of biosorption sites has an exponential distribution and a higher temperature enables the energy barrier of biosorption to be overcome. The physical adsorption the free energy change $\left(\Delta G^{\circ}\right)$ ranges from $(-20$ to 0$) \mathrm{kJ} / \mathrm{mol}$ and for chemical adsorption it ranges between (-80 and -400) $\mathrm{kJ} \mathrm{mol}^{-1}$. The $\Delta G^{\circ}$ for metal ions biosorption onto $C$. siliqua was in the range of $(-2.97$ to $-7.75) \mathrm{kJ} \mathrm{mol}^{-1}$ and so the biosorption was predominantly physical biosorption. A positive value of $\Delta S^{\circ}$ as 69.85 $102.73 \mathrm{~J} / \mathrm{mol} \mathrm{K}$ showed increased randomness at solid solution interface during the adsorption of metal ions onto C. siliqua bark.

\subsection{FT-IR Spectroscopy Analysis}

FT-IR spectra of $C$. siliqua bark biosorbent, Figure 7 showed a number of absorption peaks reflecting its complex nature. A strong band at $3340 \mathrm{~cm}^{-1}$ results due to the stretching of the $\mathrm{N}-\mathrm{H}$ bond of amino groups and also indicative of bonded hydroxyl groups $\mathrm{O}-\mathrm{H}$. The bands at $2916 \mathrm{~cm}^{-1}$ and $2846 \mathrm{~cm}^{-1}$ could be assigned to $-\mathrm{CH}$ stretching vibrations of $-\mathrm{CH} 3$ and $-\mathrm{CH}_{2}$ functional groups. The peak at $1612 \mathrm{~cm}^{-1}$ is due to $\mathrm{C}=\mathrm{O}$ stretching mode of the primary and secondary amides. The bands at $1134 \mathrm{~cm}^{-1}$ to $1473 \mathrm{~cm}^{-1}$ are indicative of the N-H stretching of the primary and secondary amides and the presence of carboxylic acids. The strong band of $\mathrm{C}-\mathrm{O}$ at $1026 \mathrm{~cm}^{-1}$ confirms the lignin structure of C. siliqua bark.

Table 3. Thermodynamic parameters of metal ions biosorption onto $C$. siliqua bark

\begin{tabular}{|c|c|c|c|c|}
\hline $\mathrm{T} / \mathrm{K}$ & $\mathrm{LnK}_{\mathrm{d}}$ & $\Delta \mathrm{G}^{\mathrm{o}}$ & $\Delta \mathrm{H}^{\mathrm{o}}$ & $\Delta \mathrm{S}^{\mathrm{o}}$ \\
\hline $\mathrm{NI}(\mathrm{II})$ & & $\mathrm{KJ} / \mathrm{mol}$ & $\mathrm{KJ} / \mathrm{mol}$ & $\mathrm{J} / \mathrm{mol} \mathrm{K}$ \\
\hline 293 & 1.22 & -2.97 & 20.56 & 80.24 \\
303 & 1.47 & -3.71 & & \\
313 & 1.76 & -4.56 & & \\
\hline $\mathrm{Zn}(\mathrm{II})$ & & & & \\
\hline 293 & 1.68 & -4.09 & 16.38 & 69.85 \\
303 & 1.89 & -4.76 & & \\
313 & 2.11 & -5.49 & & \\
\hline $\mathrm{Cu}(\mathrm{II})$ & & & & \\
\hline 293 & 1.98 & -4.26 & 17.91 & 77.54 \\
303 & 2.21 & -5.57 & & \\
313 & 2.45 & -6.38 & & \\
\hline $\mathrm{Cd}(\mathrm{II})$ & & & & \\
\hline 293 & 2.34 & -5.72 & 24.39 & 102.73 \\
303 & 2.67 & -6.73 & & \\
313 & 2.98 & -7.75 & & \\
\hline
\end{tabular}

Figure 8 shows the spectrum of $C$. siliqua bark after the sorption of metal. The peak at $3340 \mathrm{~cm}^{-1}$ corresponding to the stretching of $\mathrm{N}-\mathrm{H}$ bond of amino group and bonded hydroxyl O-H group shifts to the lower frequency $3263 \mathrm{~cm}^{-1}$ after metal take up. Thus, it can be concluded that the amino groups may be the main biosorption site for metal attachment on the $C$. siliqua bark. In addition the FT-IR spectrum shows the shift in peak at wavenumber $1612 \mathrm{~cm}^{-1}$ to $1604 \mathrm{~cm}^{-1}$ suggests that metal ions interacts with the carbonyl functional group present in C. siliqua bark. Hence, FT-IR spectra indicated that the functional groups $\mathrm{N}-\mathrm{H}, \mathrm{O}-\mathrm{H}$ and $\mathrm{C}=\mathrm{O}$ present on $\mathrm{C}$. siliqua bark surface are involved in metal biosorption process.
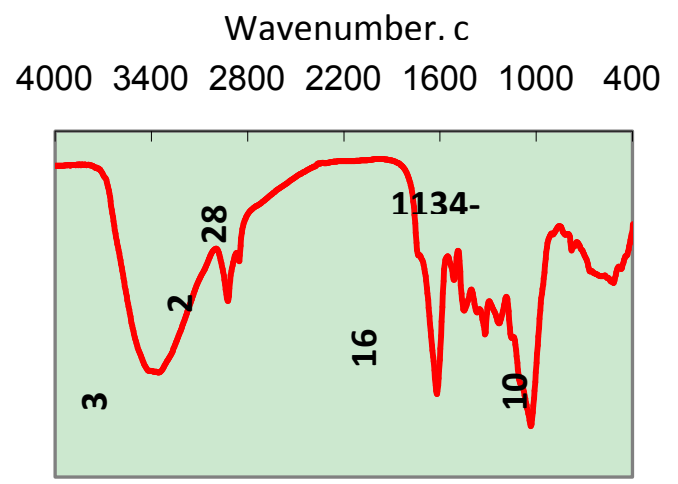

Figure 7. FT-IR of spectra of C. siliqua bark before biosorption of metals

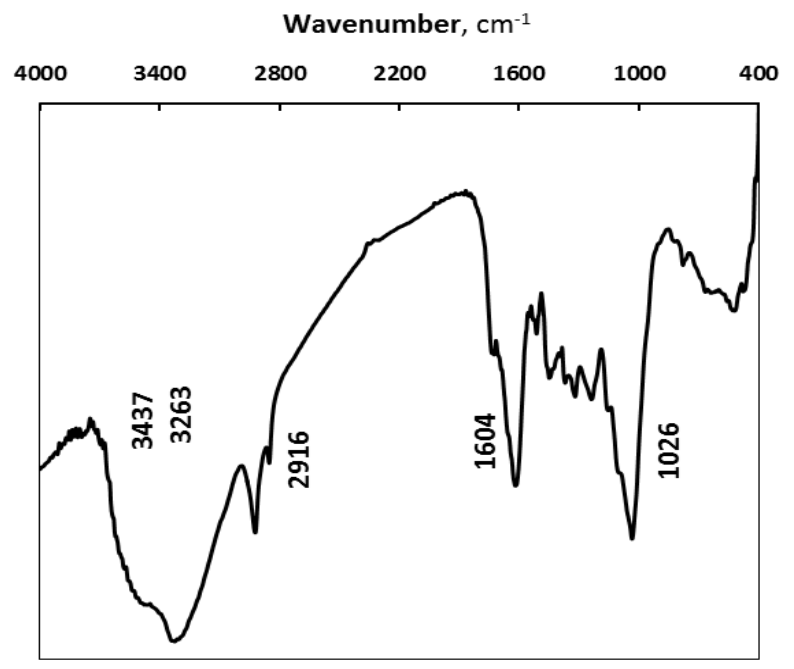

Figure 8. FT-IR of spectra of C. siliqua bark after biosorption of metals

\section{Conclusions}

Biosorption by C. siliqua bark is a safe, ecofriendly and effective method for the removal of $\mathrm{Ni}(\mathrm{II}), \mathrm{Zn}(\mathrm{II}), \mathrm{Cu}(\mathrm{II})$, $\mathrm{Cd}(\mathrm{II})$ ions from aqueous solutions. Biosorption process parameters like $\mathrm{pH}$, initial metal ions concentration, biosorbent dose, contact time and temperature were studied. The kinetic results provided the best correlation of the experimental data of biosorption of metal ions onto $C$. siliqua bark by pseudo second-order equation. The biosorption isotherms could well be fitted by the Langmuir model. it can be concluded that since the $C$. siliqua bark is an easily, locally available, low-cost adsorbent and has a considerable high biosorption capacity, it may be treated as an alternative adsorbent for treatment of aqueous solutions containing $\mathrm{Ni}(\mathrm{II}), \mathrm{Zn}(\mathrm{II}), \mathrm{Cu}(\mathrm{II})$ and $\mathrm{Cd}(\mathrm{II})$ ions. 


\section{ACKNOWLEDGEMENTS}

Authors are thankful for Royal Scientific Society, Jordan University and Baghdad University for providing the necessary facilities to carry out this work.

\section{REFERENCES}

[1] O. J.Esalah, M.E.Weber, J.H.Vera. Removal of lead, cadmium and zinc from aqueous solutions by precipitation with sodium di-(n-octyl) phosphinate. Can. J. Chem. Eng. 78 (2003) 948-954.

[2] A.I. Zouboulis K.A. Matis B.G., Lanara, C.L., Neskovic. Removal of cadmium from dilute solutions by hydroxy apatite. II. floatation studies, Sep. Sci. Technol., 32: 1755-1767Kevin R. Fall, W. Richard Stevens, TCP/IP Illustrated, Volume 1 (1997). The Protocols, 2nd ed., Addison-Wesley, USA, 2011.

[3] LM..Canet, M. Ilpide. P. Seat. Efficient facilitated transport of lead, cadmium, zinc and silver across a flat sheetsupported liquid membrane mediaed by lasalocid A, Sep. Sci. Technol. 37 (2002) 1851-1860.

[4] K. Dermentiz, A. Christoforidis, E. Valsamidou, A. Loucas, $\mathrm{K}$ Greece. Removal of nickel, copper, zinc and chromium from synthetic and industrial wastewater by electrocoagulation. Inter. J. Environ. Sci. 1 (2011) 697-710

[5] V.J. Imglezakis, M.D. Loizidou, H.P. Grigoropoulou. Ion exchange of $\mathrm{Pb} 2+, \mathrm{Cu} 2+, \mathrm{Fe} 3+$, and $\mathrm{Cr} 3+$ on natural clinoptilolite: selectivity determination and influence on activity on metal uptake. J. Colloid and Interface Sci. 261 (2003) 49-54.

[6] P. T. Bolger, D. C. Szlag. Electrochemical treatment and reuse of nickel plating rinse waters. Environ. Progress, 21 (2004) 203-208.

[7] K. Dermentzis. Removal of nickel from electroplating rinse water using electrostatic shielding electrodialysis/ electrodeionization. J. Hazar. Mater. 173 (2010) 647-652.

[8] M. A. Amer, F. I. Khaili, A. M. Awwad. Adsorption of lead, zinc and cadmium ions on polyphosphate-modified kaolinite clay. J. Environ. Chem. \& Ecotoxicology, 2 (2010) 1-8.

[9] M. N. V. Prasad, H. Freitas (2000). Removal of toxic metals solution by leaf, stem and root phytomass of Quercus ilex L (holly oak). Environ. Pollution. 110 (2000) 277-283.

[10] E.-S.Z. El-Ashtoukhy, N.K. Amin, O. Abdelwahab. Removal of lead (II) and copper (II) from aqueous solution using pomegranate peel as a new adsorbent. Desalination, 223 (2008) 162-173.

[11] K. Kelly-Vargas, M. Cerro-Lopez, S. Reyna-Tellez, E. R. Bandala, J. L. Sanchez-Salas.. Biosorption of heavy metals in polluted water, using different waste fruit cortex. Physics and Chemistry of the Earth. 37-39 (2012) 26-29.

[12] E. Asrari, H. Tavallali, M. Mahnoosh. Removal of Zn(II) and $\mathrm{Pb}$ (II) ions Using Rice Husk in Food Industrial Wastewater. J. Appl. Sci. Environ. Manage. 14 (2010) 159 - 162.

[13] Q. Li, J. Zhai, W. Zhang, M. Wang, J. Zhou.. A study on adsorption of $\mathrm{Pb}(\mathrm{II}), \mathrm{Cr}(\mathrm{III})$ and $\mathrm{Cu}(\mathrm{II})$ from aqueous solution by peanut husk. Bull. Chem. Soc. Ethiop., 22,(2008) 19-26.

[14] N. A. A. Babarinde. Kinetic, equilibrium and thermodynamic studies of the biosorption of $\mathrm{Pb}(\mathrm{II}), \mathrm{Cd}(\mathrm{II})$ and $\mathrm{Cr}(\mathrm{III})$ by neem leaf. Journal of Innovative Research in Engineering and Sciences 2 (2011) 291-306.

[15] T. N. Gamze, B. Mesci. Adsorption of copper(II) and Zn(II) ions by various agricultural by-products experimental studies and modeling. Environ. Protection Eng. 37 (2011) 143-161.

[16] M. R. Sangi, A. Shahmoradi, J. Zolgharnein, G. H. Azimi, M. Ghorbandoost. Removal and recovery of heavy metals from aqueous solution using Ulmus carpinifolia and Fraxinus excelsior tree leaves. J. Hazard. Mater. 155 (2008) 513-522.

[17] A. Almasi, M. Omidi, M. Khodadadian, R. Khamutian, M.B. Gholivand. Lead(II) and cadmium(II) removal from aqueous solution using processed walnut shell: Kinetic and equilibrium study. Toxicol. Environ. Chem., 94 (2012) 660-671.

[18] F.W. Sousa, M.J. Sousa, R.N. Isadora I.R. N. Oliveira, A.G. Oliveira, R.M. Cavalcante, P.B.A. Fechine, V.O.S. Neto, D. de Keukeleire, R.F. Nascimento. Evalution of a low-cost adsorbent for removal of toxic metal ions from wastewater of an electroplating factory. J. Environ.Manag. 90 (2009) 3340-3344.

[19] M. Kazemipour, M, Ansari, S. Tajrobehkar, M. Majdz, H.R.Kermani. Removal of lead, cadmium, zinc and copper from industrial carbon developed from walnut, hazelnut, almond, pistachio and apricot stone. J. Hazard. Mater. 150 (2008) 322-327.

[20] D.L.Mitic-Stojanovic, A., Zarubica, M. Purenovic, D. Bojic, T.Andjelkovic, A.L. Bojic. Biosorptive removal of $\mathrm{Pb}^{2+}, \mathrm{Cd}^{2+}$ and $\mathrm{Zn}^{2+}$ ions from water by Lagenaria vulgaris shell. Water SA, 37 (2011) 303-312.

[21] A. M. Awwad, A. M. Farhan. Equilibrium, kinetic and thermodynamics of biosorption of lead(II), copper(II) and cadmium(II) ions from aqueous solutions onto olive leaves powder. Amer. J. Chem. 2 (2012) 238-244.

[22] A. M. Awwad, N. M. Salem. Biosorption of copper(II) and lead(II) ions from aqueous solutions by modified loquat (Eriobotrya japonica) leaves (MLL). J. Chem. Eng. Mater Sci., 3 (2012) 7-17.

[23] M. Martinez, S. Miralles, N. Hidalgo, N. Foil N, I. Villaescusa, J. Poch. Removal of lead(II) and cadmium(II) from aqueous solution by grape stalk waste. J. Hazard. Mater. 133 (2006) 203-211.

[24] H. Ucun, O. Aksakal, E. Yildiz. Copper)II) and Zn(II) biosorption on Pinus sylvestris L. J. Hazard. Mater. 161 (2009) 1040-1045.

[25] V. Mishra, C. Balomajumder, V. K. Agarwa. Biosorption of $\mathrm{Zn}$ (II) onto the surface of non-living biomass: A comaarative study of adsorbent particle size and removal capacity of three different biomasses. Water, Air, and Soil Pollution., 2011 (2010) 489-500.

[26] I. Langmuir.. Adsorption of gases on plain surfaces of glass, mica and platinum. J. Am. Chem. Soc., 40 (1918) 1361-1403.

[27] H.M.F Freundlich, W. Hellen, W. The adsorption of Cis- and Trans-Azobenzene. J Amer Chem Soc. 61 (1939) 2228-2230. 
[28] A. Aharoni, M. Ungarish. Kinetics of activated chemisorption Part 2. Theoretical models. J. Chem. Soc. Faraday Trans. 73 (977) 456- 464.

[29] Huston, N.D., Yang, R.T., 1997. Theoretical basis for the Dubinin-Radushkevich (D-R) adsorption isotherm equation. Adsorption, 3-189-185.

[30] S. Lagergren.About the theory of so-called adsorption of soluble substances. K. Sven. Vetenskapsakad Handl. 24 (1898) 1-39.
[31] M.B. Lohani, A. Singh, D.C. Rupainwar, D.N. Dhar. Studies on efficiency of guava (Psidium guajava) bark as biosorbent for removal of $\mathrm{Hg}(\mathrm{II})$ from aqueous solutions J. Hazard. Mater. , 159 (2008) 626-629.

[32] M. Ajmal, R.A.K., Rao, R. Ahmad, J. Ahmad. Adsorption studies of Citrus reticulate (fruit peel orange): removal and recovery of $\mathrm{Ni}$ (II) from electroplating wastewater, J. Hazard. Mater., 79 (2000) 117-131. 